\title{
AC 2008-1393: ENHANCEMENT OF AN ENGINEERING CURRICULUM THROUGH INTERNATIONAL EXPERIENCES
}

\section{Prashanth Jayaraman, Virginia Polytechnic Institute and State University}

Prashanth Krishna Jayaraman is a graduate student in the Department of Industrial and Systems Engineering at Virginia Tech. He is currently a Graduate Teaching Assistant in the Department of Engineering Education and helps in teaching the hands on activities of the EngE 1024 course. He is the President of the International Association for the Exchange of Students for Technical Experience at Virginia Tech. He holds a Bachelor's degree in Computer Science and Engineering from Anna University (Chennai, India).

\section{Vinod Lohani, Virginia Polytechnic Institute and State University}

VINOD K. LOHANI is an associate professor in the Department of Engineering Education and an adjunct faculty in Civil \& Environmental Engineering at Virginia Tech. He received a Ph.D. in civil engineering from Virginia Tech in 1995. His areas of teaching and research include engineering education, international collaboration and hydrology \& water resources.

\section{Garrett Bradley, Virginia Polytechnic Institute and State University}

Garrett Bradley currently works for Amsted Rail -Griffin Wheel division as an international manufacturing engineer, with current project assignment in Xinyang, Henan, China. Garrett graduated from Virginia Tech in 2007 with a Bachelor's degree in Mechanical Engineering and concentration in Green Engineering. During his academic career, Garrett actively participated in numerous international initiatives at Virginia Tech and has maintained involvement in several projects since graduating.

\section{Odis Griffin, Virginia Polytechnic Institute and State University}

Dr. Hayden Griffin is the Professor and Head of the Department of Engineering Education at Virginia Tech. His research interests include the theories of human learning, especially in an engineering context, design of effective engineering courses and curricula, and design of graduate programs in engineering education.

\section{John Dooley, Virginia Polytechnic Institute and State University}

Dr. John Dooley is the Vice President for Outreach and International Affairs at Virginia Tech and directs all international activities at the university. 


\title{
Enhancement of International Activities in a Large Engineering Curriculum
}

\begin{abstract}
About one thousand three hundred students enter Virginia Tech's College of Engineering as a freshman each year. These engineering freshmen complete a 1-year long general engineering (GE) program, conducted by the Department of Engineering Education (EngE), before transferring into one of thirteen engineering majors. This university has taken several initiatives in recent years to promote internationalization of campus. This paper presents summary of various international activities introduced in the GE program during last 3 years and students' responses are analyzed. In addition, some innovative ideas, aided by latest technology, to enhance global education experiences for engineering students are presented.
\end{abstract}

\section{Introduction:}

The General Engineering (GE) (also called freshman engineering) program at Virginia Tech is being reformed as a part of a Department-Level Reform (DLR) grant from the NSF.

"Engineering Exploration EngE1024," is a 2-credit first semester course in the GE program. This course, required of all engineering freshmen, is offered by the Department of Engineering Education (EngE). Some of the recent initiatives in EngE1024 include introduction to sustainability concepts ${ }^{\mathrm{i}}$; use of contemporary issues and skits to instruct engineering ethics ${ }^{\text {ii iii }}$; introduction of international activities ${ }^{\text {iv }}$; use of electronic portfolio for instruction ${ }^{\mathrm{v} \text { vi }}$; use of multiple models of a problem to instruct different aspects of the course ${ }^{\text {vii }}$, introduction of international content, and use of mechatronics to introduce multi-disciplinary design to engineering freshmen ${ }^{\text {viii }}$. Also, a number of assessment (formative and summative) activities are being implemented in the GE program ${ }^{\mathrm{ix} x}$ to evaluate the learning experiences of engineering freshmen.

This paper summarizes the efforts made to bring international content into EngE 1024 for the last 3 years. Global education related issues raised in national publications like The Engineer of 2020 by the National Academy of Engineering (NAE) are discussed in EngE1024 lessons. Students are made aware of thought provoking questions raised in The Engineer of 2020: "Do U.S. engineers understand enough culturally, for example, to respond to the needs of the multiple niches in a global market?", "Can we continue to expect everyone else to speak English?"xi Another follow up report of the NAE includes an article that states the following about the U.S. Engineer of 2020 and beyond: "It is expected that U.S. engineers will be based abroad, will have to travel (physically or virtually) around the world to meet customers, and will have to converse proficiently in more than one language. Flexibility and respect for ways to life different from ours will be critical to professional success. "xii In addition, quotes by national level academicians and CEOs highlighting importance of global education are shared with students. For example: Frank Rhodes, President Emeritus, Cornell University says: "The [New American University] will be international in its orientation and cosmopolitan in its character; study abroad will become a norm. "xiii 
In order to receive students' feedback, in-class and out-of-class assessment tools have been developed. A summary of data collected for last 3 years has also been presented.

\section{Hands-on Activities with International Flavor in EngE1024}

Examples of hands-on activities that directly expose freshmen to international engineering and education issues include: i) World map activity and ii) Sustainable energy design project (SEDP). Following sections provide relevant details.

\subsection{World Map Activity}

This activity was developed to introduce students to an international perspective on global energy issues. Students work in small groups in a workshop (90-min long) part of EngE1024. They are provided with a world map, Lego blocks, and data for several countries, and, are asked to construct three dimensional models of population, oil supply and oil demand (see Figure 1 [a] and [b]). For example, in fall 2007 relevant data for following countries were provided: Brazil, India, China, USA, Nigeria, Russia, etc.

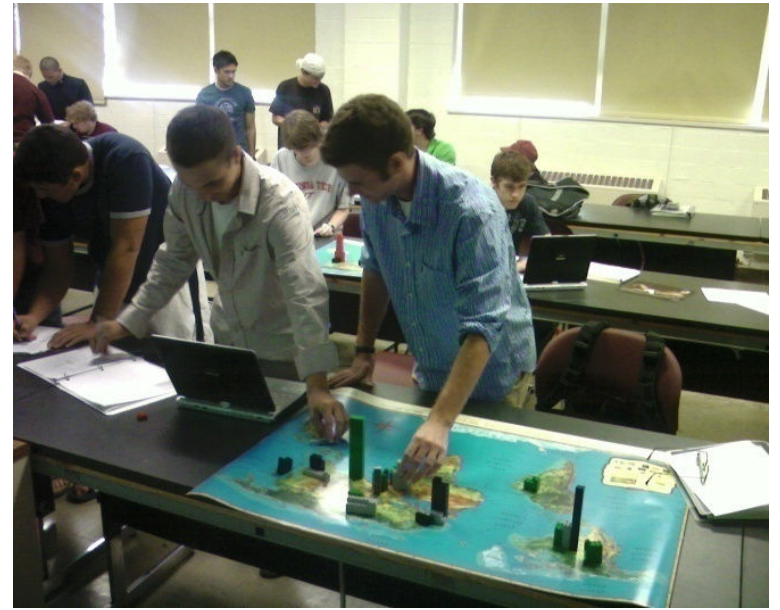

Figure 1 [a]: Students taking part in World Map activity in class.

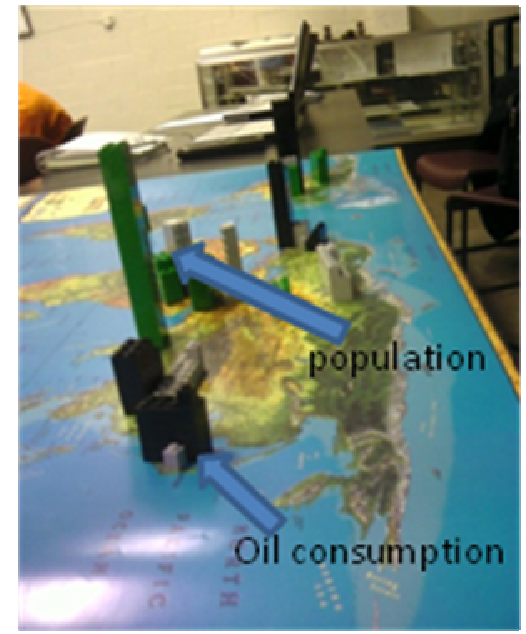

Figure 1 [b]: Lego Blocks showing the oil consumption and production along with population

In addition to creating Lego models, students are asked to complete a worksheet which includes calculation and graphing of projected populations of different countries, using an exponential growth model as below, determining the consumption and production of oil, and discussing current environmental issues using reliable online resources.

$P_{t}=P_{o} e^{r t}$

$\mathrm{P}_{\mathrm{t}}=$ estimated population after $\mathrm{t}$ years

$\mathrm{P}_{\mathrm{o}}=$ current population (in 2007)

$\mathrm{r}=$ population growth rate (annual)

$\mathrm{t}=$ number of years

One the topics in EngE1024 includes fitting of various types of empirical functions, namely, linear, power, and exponential, using the method of selected points and least squares regression. 
In past, bookish data was used for this purpose. But, in recent years students have been provided real world data, for example, on population growth, literacy rate, etc., from various countries to fit these functions. Some thought provoking questions included in the worksheet are: In your group's opinion, what are the international implications of a country's dependence on fossil fuels (oil, coal, natural gas)? Suppose you live in one of such countries and are in-charge of the Federal Department of Energy. List 3-4 key research issues that will be on your priority list.

List 3 to 4 of the most common "Environment - Current Issues" among all countries listed

In spring 2008, a pre- and post-test was implemented to analyze learning gains from this activity. While the analysis of data is ongoing at the time of this writing, preliminary results show that this activity improved students' global awareness and motivated them to pursue green engineering practices.

\subsection{SEDP: Sustainable Energy Design Project}

A "Sustainable Energy Design Project (SEDP)" was piloted in the fall 2006 with approximately 1,200 engineering freshmen enrolled in EngE 1024 course. Students were asked to design and construct a "promotional invention" that promoted awareness of a renewable energy source. Each team was assigned one of five renewable energy topics (namely, hydropower, geothermal, solar, wind, and biomass) by their instructor. They were instructed to assume that the audience was the general public, who may have limited knowledge of renewable energy sources. The following parameters were to be considered in their design solution:

-It should be functional, safe, and interesting.

-It must highlight one or more key components of a renewable energy source.

-It should strive to educate and entertain as well as generate further inquiry and interest in renewable energy sources.

-It should aim to have broad appeal across gender, age, race, and nationality.

More details on this activity can be found in an ASEE conference paper titled "Sustainable Energy Design Projects for Engineering Freshmen. "xiv Prior to the implementation of the SEDP, the EngE 1024 course incorporated a Sustainable Development Design Project (SDDP) without a focus on sustainable energy sources. The primary objectives of this project were to provide students with a challenging and real world problem from which to have an educational hands-on experience with certain fundamental aspects of the engineering design process. An exit survey conducted at the end of the project indicated that only about 30 percent of the students felt that the project increased their interest in engineering, about 25 percent of the students believed that the project increased their global awareness and about 20 percent believed that the project made them more socially conscious. ${ }^{\mathrm{xv}}$

Table 1 shows results for the Sustainable Energy Design Project from an exit survey that was conducted at the end of fall 2007. Several student teams came up with designs that address energy issues in developing countries. Some examples include Micro Hydro/Solar Portable Power Generator, Solar Powered Well, Solar Powered Hot Water Heater, and Biomass Water Heater 


\begin{tabular}{|c|c|c|c|}
\hline \multicolumn{2}{|c|}{$\begin{array}{l}\text { I see the relevance of sustainability } \\
\text { in engineering design ( } 536 \\
\text { responses): }\end{array}$} & \multicolumn{2}{|c|}{$\begin{array}{l}\text { My understanding of the } \\
\text { engineering design process } \\
\text { increased as a result of the } \\
\text { hands-on design projects in } \\
\text { ENGE } 1024 \text { ( } 536 \text { responses): }\end{array}$} \\
\hline Strongly agree & $(43 \%)$ & Strongly agree & $(27 \%)$ \\
\hline Agree & $(47 \%)$ & Agree & $(49 \%)$ \\
\hline Neutral & $(6 \%)$ & Neutral & $(14 \%)$ \\
\hline Disagree & $(1 \%)$ & Disagree & $(8 \%)$ \\
\hline $\begin{array}{l}\text { Strongly } \\
\text { disagree }\end{array}$ & $(2 \%)$ & $\begin{array}{l}\text { Strongly } \\
\text { disagree }\end{array}$ & $(2 \%)$ \\
\hline no answer & $(1 \%)$ & no answer & $(0 \%)$ \\
\hline
\end{tabular}

Table 1: Survey Results on SEDP, Fall 2007 Data

The World Map Activity complemented the SEDP well by creating awareness of oil consumption in various countries and demonstrated a need for replacing fossil fuels with renewable energy. It's expected that these activities will present a broad perspective to engineering freshmen and it is hoped that they would be able to understand the global impact of engineering design on the environment and are able to appreciate the need for environmentally friendly alternatives.

\section{Efforts to bring international content into the freshman engineering classroom}

\subsection{Study Abroad Presentations}

The Study Abroad office at Virginia Tech provided information on the number of students participating in study abroad programs between the years 2001 and 2005 (see fig.2) which accounts for approximately $4 \%$ of the entire student population. Although exclusive data for College of Engineering (COE) was not available, it is known that the COE's share in these numbers is very small. In order to expose engineering freshmen to global engineering education and encourage them to pursue study abroad opportunities, an initiative was taken beginning in spring 2005 to invite engineering seniors with study abroad experiences to share their experiences with engineering freshmen as part of EngE1024 course. 


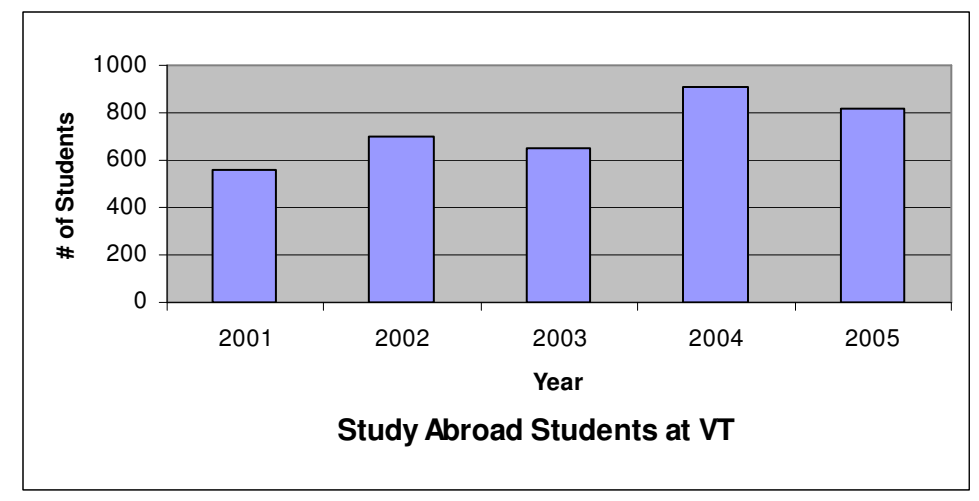

Figure 2: Study abroad students at VT (Source: VT Study abroad office, web site: www.educationabroad.vt.edu)

Since the commencement of study abroad presentations more than 25 students with experiences in various countries including Australia, India, China, Ireland, Italy, South Africa, France, Spain, Russia, etc. have shared their experinces with engineering freshmen. Data has been systematically collected over the past few years to analyze the influence of study abroad presentations on students' inclination to participate and to gain an understanding on factors influencing their decisions.

Starting fall 2004, a survey has been administered in EngE1024 course at the beginning of the semester to document freshmen's background and prior experiences. In fall 2005, a study abroad related question was added to this survey. A summary of data collected along with the question is given in the table 2.

\begin{tabular}{|c|c|c|}
\hline Survey Question: & $\begin{array}{l}\text { I would consider st } \\
\text { engineering progra } \\
\text { following (check all }\end{array}$ & $\begin{array}{l}\text { d as part of my } \\
\text { provided with of the } \\
\text { )? }\end{array}$ \\
\hline Options: & $\begin{array}{c}\text { Fall } 2005 \\
(\%)(\mathrm{n}=\sim 1000)\end{array}$ & $\begin{array}{l}\text { Spring } 2006 \\
(\%)(n=\sim 150)\end{array}$ \\
\hline $\begin{array}{l}\text { No, I am not interested in a study } \\
\text { abroad program. }\end{array}$ & 33.7 & 31.5 \\
\hline $\begin{array}{l}\text { Yes, if the courses I take transfer } \\
\text { to Tech }\end{array}$ & 45.5 & 49.7 \\
\hline $\begin{array}{l}\text { Yes, if I find an interesting study } \\
\text { abroad program }\end{array}$ & 48.5 & 44.8 \\
\hline Yes, if I find financial aid & 34.6 & 31.5 \\
\hline
\end{tabular}

Table 2: Study Abroad Data from Students’ Background Survey 
In addition, in-class clicker based surveys or polling have been conducted to find out percentage of students who are or aren't interested in pursuing study abroad options in future. Table 3 gives response to an in-class survey question in EngE1024 lecture class from November, 2007 ( 131 respondents).

\begin{tabular}{|l|l|}
\hline Options & $\begin{array}{l}\text { Number of } \\
\text { Students }\end{array}$ \\
\hline Very useful and it motivated me to consider study abroad options in future & $41 \%$ \\
\hline Useful but it's too early to make plans for studying abroad & $18 \%$ \\
\hline Useful but I'm not interested in studying abroad & $19 \%$ \\
\hline None of the above & $5 \%$ \\
\hline Misc. Response & $17 \%$ \\
\hline
\end{tabular}

Table 3: Study abroad presentation survey response, Fall 2007 data

Based on the data we have collected over past semesters, a plot is generated showing percentage of students uninterested in study abroad over the past three years. It can be seen in figure 3 that there has been a steady decline, in the number of students who aren't interested in pursuing study abroad option, ending at 19\% in our most recent survey in November 2007.

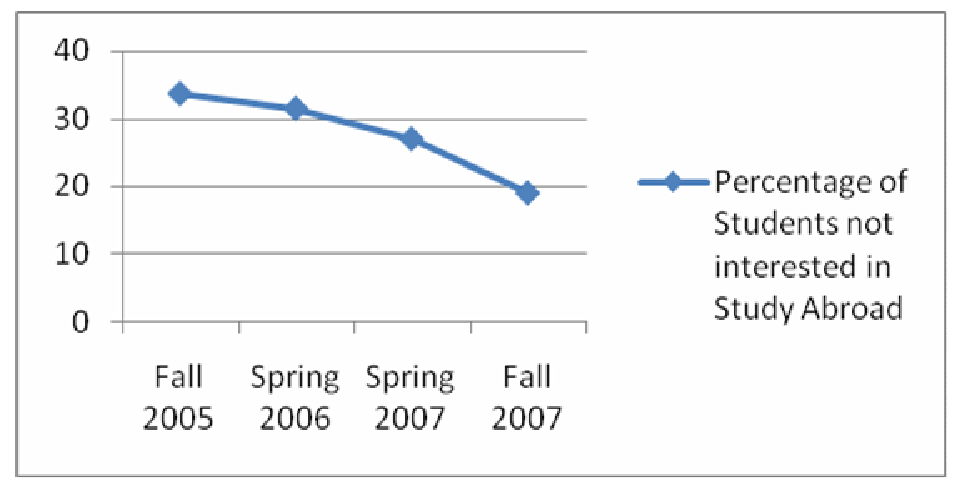

Figure 3: Students who are not interested in pursuing Study Abroad possibilities (2005-07)

It is evident that students enter the engineering program with an open mind for pursuing study abroad programs. It is the responsibility of educators to motivate and prepare them for global education. In fall of 2007, we encouraged our students to attend The Engineering Education Abroad Fair hosted by the Student Engineers Abroad Council at this university. Two posters were presented by the Department of Engineering Education at this fair- "Internationalizing the Freshman Engineering Program" xvi and "Implementation of International Activities in a Freshman Engineering Course"xvii. Many of our freshman students attended this fair and were exposed to numerous on-campus organizations offering a variety of international programs.

\subsection{International Remote Interactive Learning}

The CoE at Virginia Tech announced a new Tablet PC computing initiative in summer 2006 for incoming freshmen. This initiative made it mandatory for all engineering freshmen $(\sim 1300$ each year) to own a Tablet PC starting fall 2006 for use in engineering instruction. In fall 2007, an 
instruction software DyKnow was used with Tablets to make classroom environment interactive and student friendly. This software allows a student to attend class from a remote location and also makes it possible for the instructor to teach class from a remote location. The second author took advantage of this capability of the software and decided to do a test of teaching an EngE1024 lesson from Coimbra, Portugal where he attended an International Conference on Engineering Education.

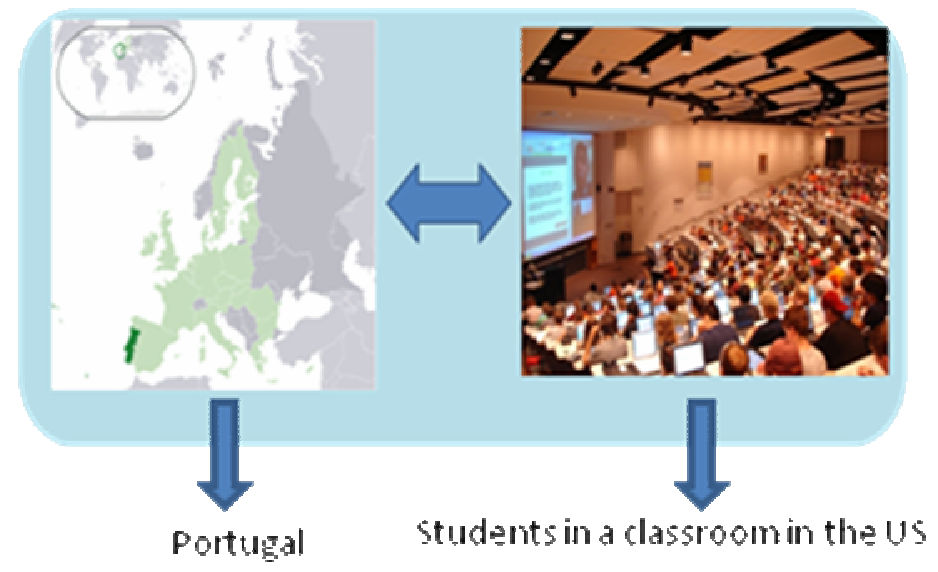

Fig. 4.a: Remote Learning session from Portugal to a classroom in the US A special lecture session was set up using the Tablet PC software DyKnow and freeware communication tool Skype. The content of the lecture consisted of an introduction to this old University in Portugal, brief description of the conference, brief description of the travel route the author took to reach Coimbra, and geography of the western European region. Following these descriptions, the author went on to discuss the topics (introduction to graphics) assigned for the week.

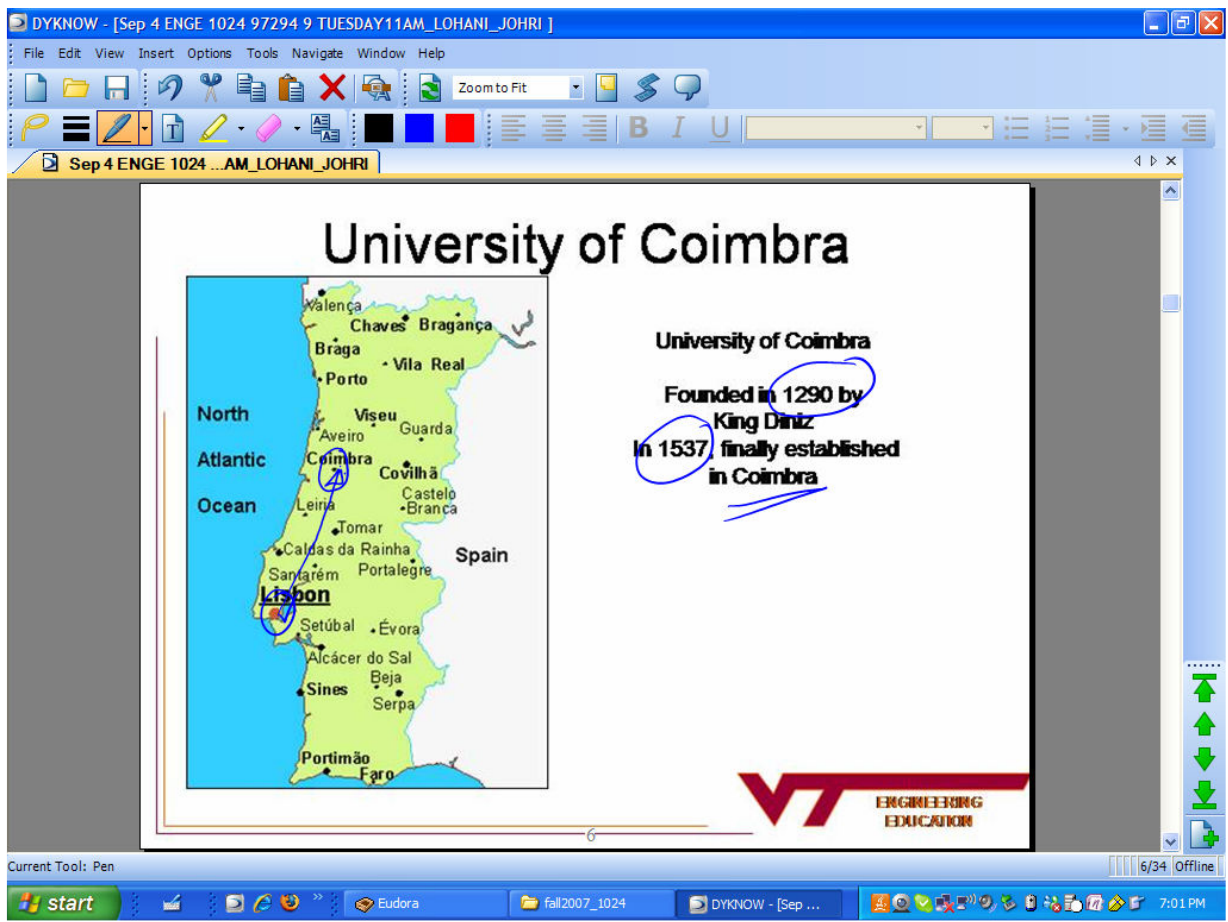


Fig. 4.b: Screenshot of DyKnow software showing discussion of travel route to Coimbra, Portugal

The setup needed webcams at each end, an audio output and a video projector- this setup is illustrated in the sequence of pictures in figure 4.c. Skype enabled us to facilitate audio/video communication at both ends, while Dyknow Tablet PC software provided the instructor the capability of working on engineering problems that were dynamically reflected on each student's tablet PC.

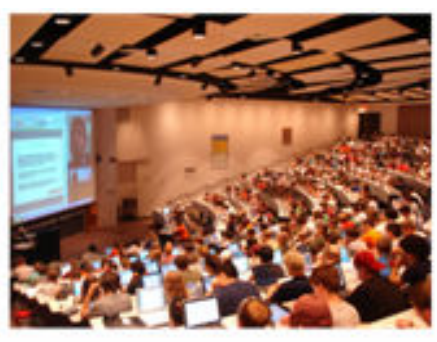

Students in the freshman engineering classroom at VT campus follow the professor on screen.

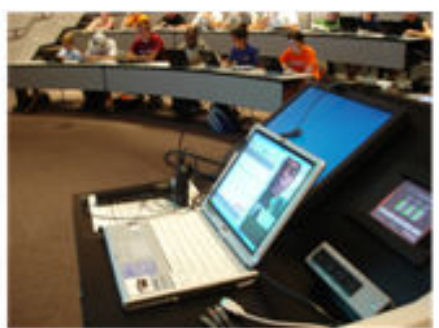

The hardware setup in the classroom to facilitate communication

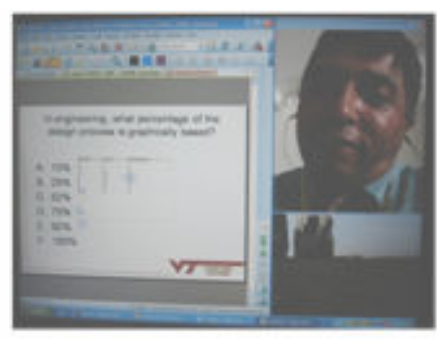

The software used for this coursetablet PC software DyKnow and Skype for audio visual communication

Figure 4.c: Components of the remote interactive learning session.

A survey was conducted at the end of this session to analyze students' reaction to remote instruction from Portugal. Students were questioned on their perception of this remote learning experience compared to a normal in-class teaching experience, the influence of this lecture on their plans to study abroad, and their likes and dislikes about remote learning. The survey questions and sample responses are given below:

Compared to your average experience with other lectures, how satisfied are you with the lecture from Portugal:
A. More satisfied $13 \%$
B. Equally Satisfied $63 \%$
C. Less Satisfied $24 \%$

D. Not in class $0 \%$

E. Other 1

F. No Answer 0\%

Did Dr. Lohani's presentation from Portugal motivate you to consider study abroad opportunities in coming years?

Thought about it $39 \% \quad$ B. Too early to think about study abroad 24\% C. Not Sure 20\%
D. Not at all $14 \%$
E. Other $4 \%$
F. No Answer 0\%

List three things that you liked about this presentation/experience:

- We learned interesting facts about Portugal

- Consistency of the same teacher regardless of where they may have traveled

- Made me think about the future of school.....we could be millions of miles apart

List three things that you did not like about the Portugal presentation:

-He couldn't really move around and be as enthusiastic as Dr. Lohani usually is. 
- There wasn't anything I didn't like about it.

-Unable to ask questions as easily if people are confused

\section{What would you like to see in this presentation from abroad other than covering lecture material?}

-Telling us how we could be the one abroad.

-To continue on the topic of how foreign countries are handling global issues in relation to the US.

- What engineering opportunities there are in that country?

\subsection{Experiences from International Conferences}

In March 2007, the lead and third author (i.e., student authors) attended a 2-part international conference on globalization called INNOVATE that was held in Beijing, China and Bangalore, India. The conference involved undergraduate and graduate students from five different countries (namely Singapore, Japan, United States, China and India) with a majority of students from the United States $^{\text {xviii }}$. The authors along with other delegates got the opportunity to examine the relationship between technology, globalization, and leadership in Asian countries by taking part in lectures and panel discussions delivered by business, academic, and government leaders.

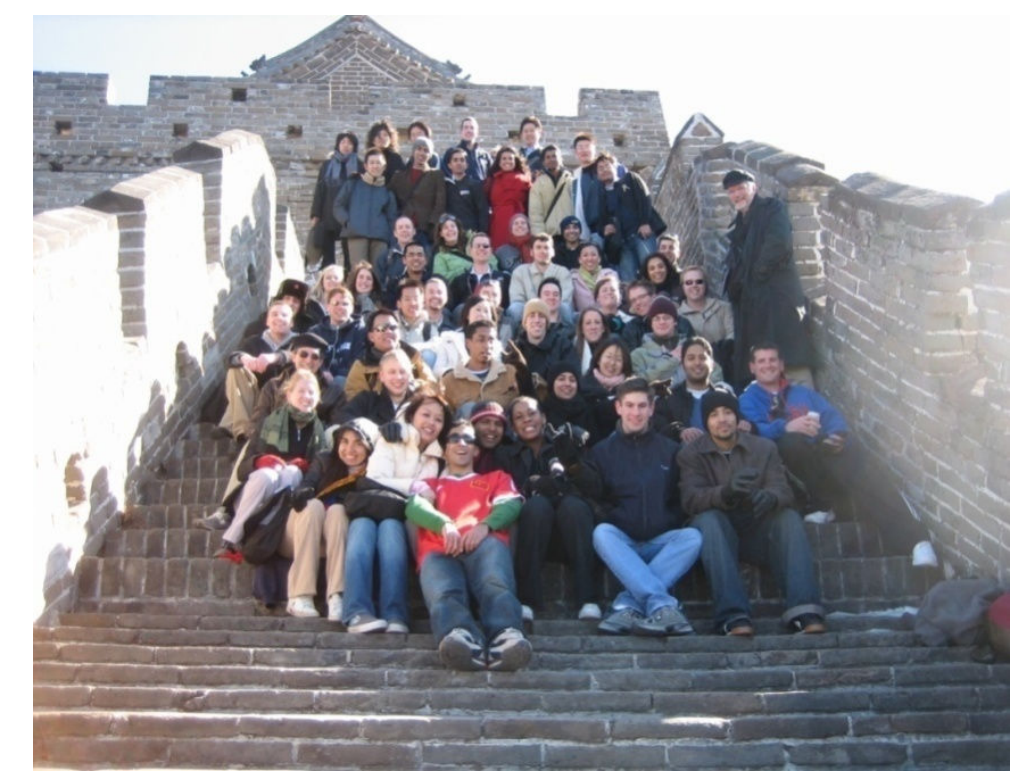

Fig. 5: INNOVATE conference delegates at the Great Wall of China.

Upon their return, the student authors made a series of presentations at the freshman engineering class in fall ' 07 and spring '07 on globalization, as well as on social, economic and political conditions in both India and China. A website was designed for students to access information on their conference experiences which contained pictures and text on company visits and social gettogethers. The results of a survey that was conducted in class after the presentations are shown in Table 4. 
I found the Study Abroad Presentations [on Innovate], (number of respondents: 206):

\begin{tabular}{|l|l|}
\hline Options & $\begin{array}{l}\text { Number of } \\
\text { Students }\end{array}$ \\
\hline Very useful and it motivated me to consider study abroad options in future & $19 \%$ \\
\hline Useful but it's too early to make plans for studying abroad & $35 \%$ \\
\hline Useful but I'm not interested in studying abroad & $27 \%$ \\
\hline None of the above & $16 \%$ \\
\hline Misc. Response & $3 \%$ \\
\hline
\end{tabular}

Table 4: Survey result from INNOVATE presentations in EngE1114 class

In addition, the student authors surveyed their fellow delegates to seek their views on globalization, conference experience and impact of the conference on their personal development. The objective of the survey was to share this information with engineering freshmen. The authors discovered that Rice University, organizers of the INNOVATE conference, arranged for delegates to attend an online class few months prior to the conference in order to provide them with relevant background information. The survey participants opined that the preparatory material provided before the conference played a vital role in enhancing their understanding of recent developments in Asia. The authors believe that good preparatory material available in more than one media-books, internet, audio (pod casts) etc. - is highly essential for having a successful study abroad experience.

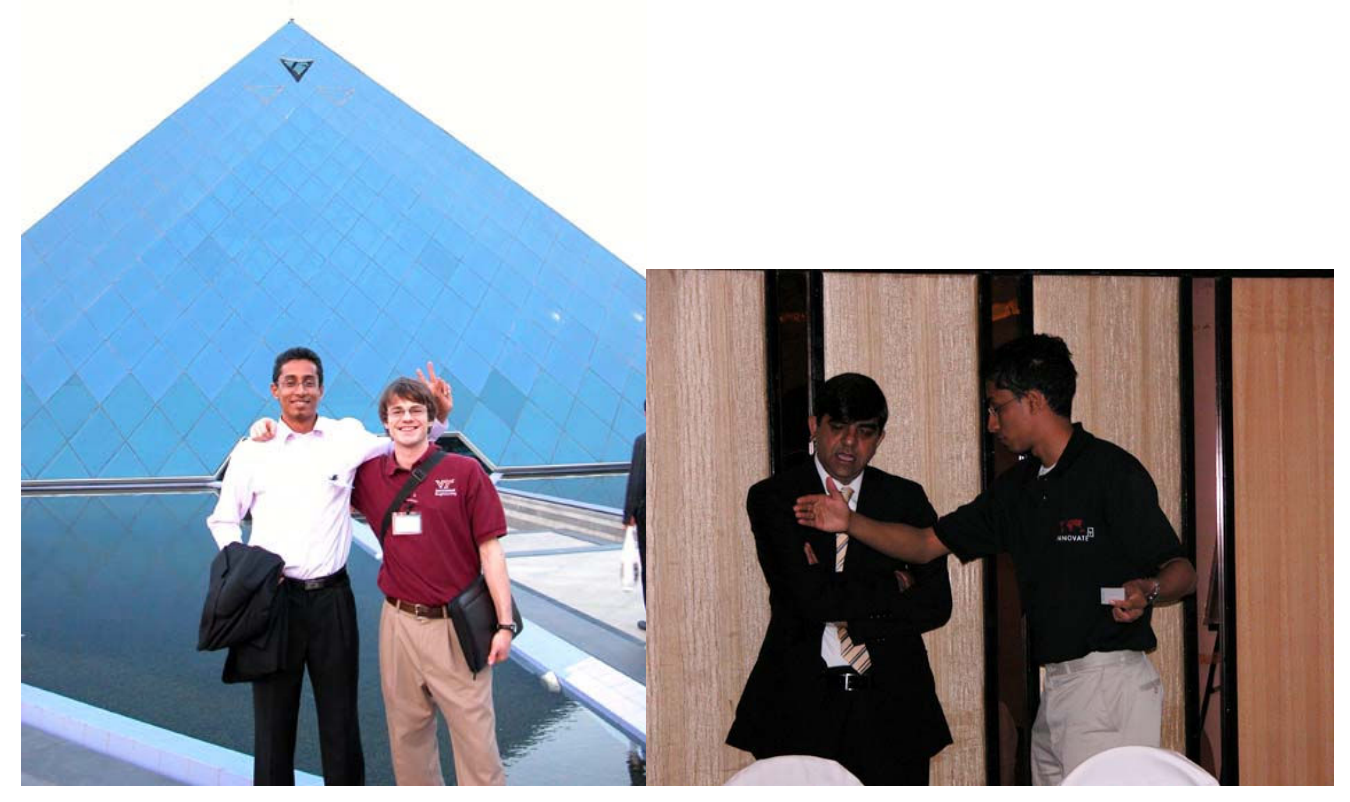

Fig 6. Student Authors in Infosys Technologies, Bangalore, India (L) Lead author discusses with one of the panelists in Bangalore, India. (R) 
In order to analyze the financial aspects associated with study abroad programs/conferences, the student authors also examined the influence of cost on delegate's decision to attend the conference. It may be noted that the total cost of the conference was \$2300 US\$, and included the conference fee, air travel, accommodation and transportation. We analyzed the influence of the cost of conference on delegates' decision to attend the conference. Below, the graph represents the decision of students to attend the conference and the willingness to pay a percentage of the conference expenses. It can be seen from figure 7 that many students, close to forty percent, were willing to pay the entire cost of attending the conference. This information will be presented to engineering freshmen in spring 2008 as part of the study abroad presentation session in EngE1024.

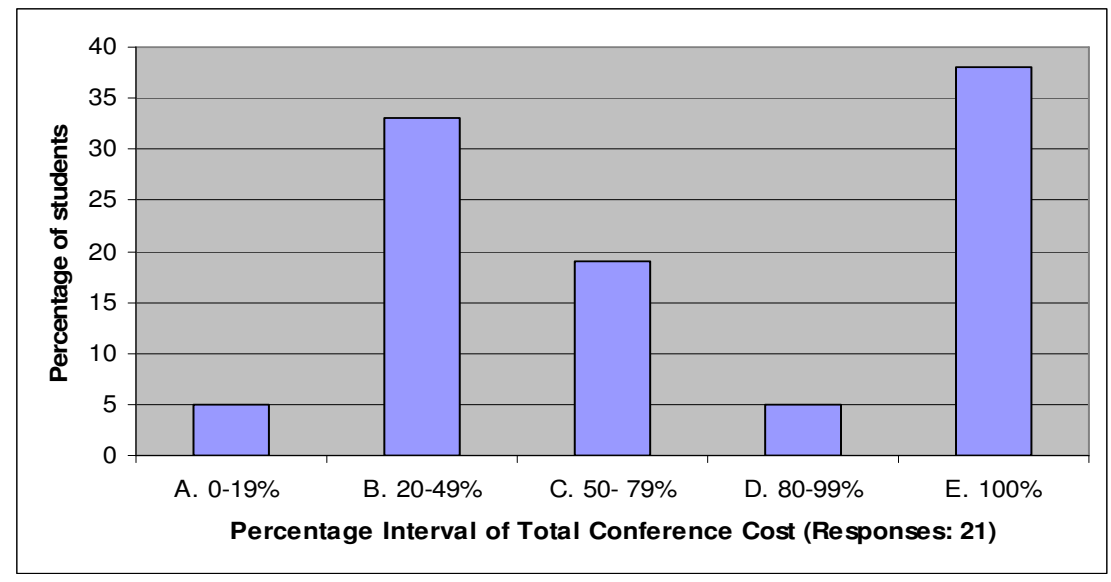

Fig. 7: Survey result from INNOVATE conference on funding

\subsection{Experiences from Work Abroad Programs}

The International Association for the Exchange of Students for Technical Experience (IAESTE), a confederation of national committees, provides a platform for students of higher education with international technical experience relevant to their studies. The third author had an opportunity of working as a technical intern in China through IAESTE. He interned with Shanghai Huizhong Automotive Manufacturing Co. Ltd (SHAC) in its Product Engineering Department (see fig. 8). He used AutoCAD to create 2D representations for gas, clutch and brake pedal models.

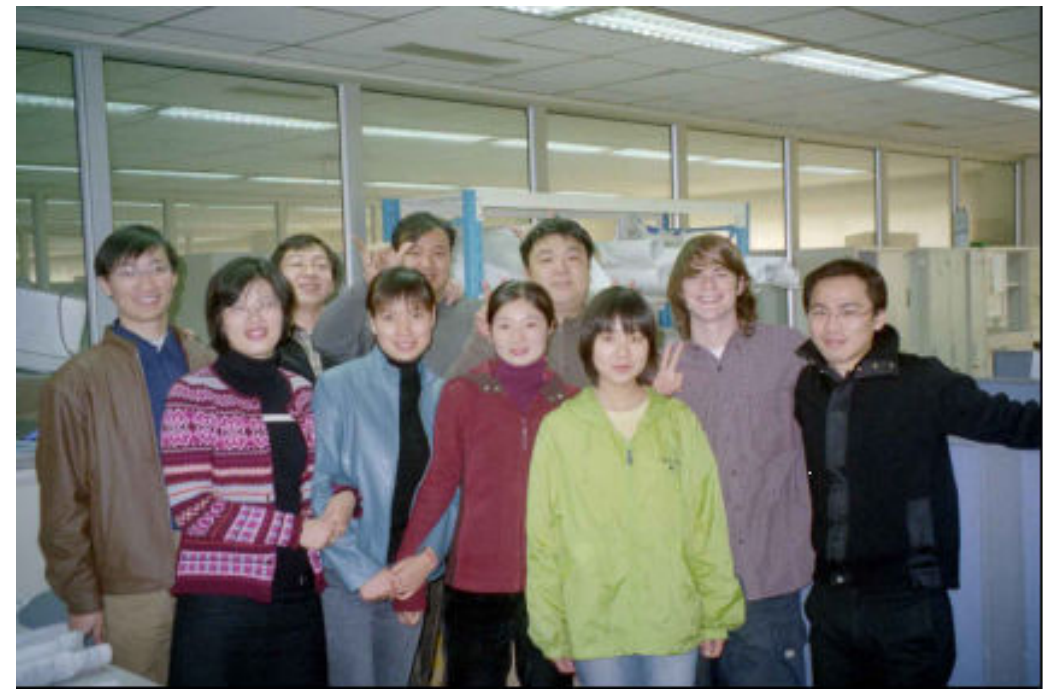


Fig. 8: Student Author Garrett Bradley (second from right) with his co-workers at Shanghai Huizhong Auto Co.

It is this author's belief that an international internship should ideally be between 4 and 6 months; a stay shorter than four months would be too less to get immersed in the culture, and, a stay longer than six months, would make engineering curriculum quite challenging upon return. While a short international experience might be suitable for a sophomore eager to travel the world, a six month international program is suitable for juniors or seniors with greater technical knowledge. This author also suggests that in order to understand the culture and traditions of the region it is essential to live with native roommates, use public transportation and attempt to speak the language. It may be mentioned that the author gained a good proficiency in Chinese and has extensively traveled the world on study abroad programs, international humanitarian projects apart from this international internship. His internship experience in China, interaction with the locals there and international students at our university has encouraged him to accept a full-time position in China after his graduation in May 07.

In order to analyze students' study preferences for geographic regions, another survey was conducted in November '07 in EngE1024 class. It was observed that only seven percent of students wished to pursue study abroad opportunities in Asia (see Table 5). Intuitively, one can attribute this avoidance of Asian countries to apprehension about culture, language and sociopolitical conditions in those regions.

\begin{tabular}{|l|l|}
\hline \multicolumn{2}{|l|}{$\begin{array}{l}\text { If you are to choose a region to studying abroad, where would you like to go (FIRST } \\
\text { preference)? }\end{array}$} \\
\hline Options & Number of Students (Percentage) \\
\hline Europe & $37 \%$ \\
\hline Asia & $7 \%$ \\
\hline Australia/New Zealand & $22 \%$ \\
\hline South America & $5 \%$ \\
\hline I'm not considering Study Abroad & $8 \%$ \\
\hline Misc. Response & $22 \%$ \\
\hline
\end{tabular}

Table 5: Study Abroad Presentation response (Nov. 2007, sample size: 100 students)

The first two authors plan to create an interactive remote presentation from China this semester, similar to the one from Portugal, with the third author presenting his experiences and recommendations for freshman students who are eager to gain international exposure. We believe that his presentation would strike a chord amongst students as he is an alumnus and even inspire those who are not considering study/work abroad programs to rethink. Moreover, we hope that this session would clear any preconceived notions that students might have about Asia and would encourage them to boldly pursue both study and work abroad opportunities in that region.

\section{Summary}

A number of initiatives have been undertaken since spring 2005 to make engineering freshmen aware of global engineering and education issues at this university. Assessment data indicates 
that these initiatives have been successful in planting seeds early on to pursue global education. The College of Engineering is actively pursuing a college wide approach of encouraging international education and it is expected that the number of students opting for study abroad options will significantly increase in coming years.

Student associations such as the International Association for the Exchange of Students for Technical Experience and Engineer's Without Border enrich the internationalization policies of the College by providing more avenues to gain global exposure. This spring another student from Virginia Tech plans on attending the INNOVATE conference on globalization, to be held in Vietnam and Singapore in March 2008. Once again, we hope to capture and preserve his conference experiences effectively and present it to our students. The Engineering Education department is constantly making efforts to bring international content into freshman engineering courses. The four keywords that describe the mission of the department are: inventive, inclusive, interdisciplinary, and international. Second author has started a new project in fall 2007 , supported by the Funds for Post-Secondary Education (FIPSE) program of the department of education, in collaboration with two US universities including the NCSU and NCA\&T and three universities in Brazil including Universidade Federal do Rio de Janeiro, Pontificia Universidade Católica do Paraná, and Universidade Federal do Juiz de Fora. The objective is to take engineering students to Brazil for a semester long study and bring Brazilian students to Virginia Tech for the same period.

\section{Acknowledgement}

The authors would like to thank all instructors and the Graduate Teaching Assistants, particularly Dr. Jenny Lo, Jennifer Mullin and Ricky Castles, involved in EngE1024 course for their constructive feedback and assistance in implementation of various international activities in this course. Thanks are also due to the engineering seniors who agreed to share their study experiences with freshmen. Finally, financial support from the NSF (DLR program grant \# 0431779) is very sincerely acknowledged. The student authors would like to specifically thank the officials in the Department of Engineering Education and the Office of International AffairsOutreach and College for generously funding a part of their INNOVATE conference expenses, and College of Engineering- International Programs for supporting the IAESTE program at Virginia Tech.

\section{References}

\footnotetext{
${ }^{\mathrm{i}}$ Mullin, J.S., Lohani, V.K., Lo, J.L., and Griffin, O.H., "Sustainable Development Design Projects for Engineering Freshmen," Proceedings of the 2006 ASEE Annual Conference and Exposition, Chicago, IL, June 18-21, 2006a. ii Lo, J.L., Lohani, V.K., and Mullin, J.S., "Student Presentations on Contemporary Engineering Ethics Issues in an Introductory Freshman Engineering Course," Proceedings of the 2006 ASEE Annual Conference and Exposition, Chicago, IL, June 18-21, 2006 b.

${ }_{\text {iii }}$ Mullin, J.S., Lohani, V.K., and Lo, J.L., "WIP: Introduction to Engineering Ethics through Student Skits in the Freshman Engineering Program at Virginia Tech," to be published in the Proceedings of the 2006 Frontiers in Education Conference, San Diego, CA, October 27- November 1, 2006b.

iv Lohani, V., and Mullin, J. S., 2006. "International activities in a freshman engineering course," Poster presented at the International Education Fair, spring 2006, College of Engineering, VT.
} 
${ }^{\mathrm{v}}$ Knott, M., Lohani, V.K., Griffin, O.H., Loganathan, G.V., Adel, G., Paretti, M., Wolfe, M., Mallikajunan, K., and Wildman, T., "Using e-portfolios in a large engineering program," Proceedings of the 2005 ASEE Annual Conference and Exposition, Portland, Oregon, June 12-15, 2005.

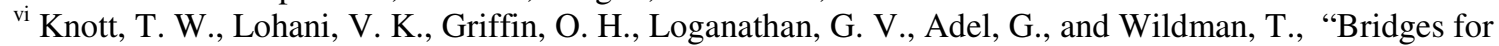
Engineering Education: Exploring e-Portfolios in Engineering Education at Virginia Tech," Proceedings of the 2004 ASEE Annual Conference and Exposition, Salt Lake City, Utah, June 20-23, 2004.

${ }^{\text {vii }}$ Connor, J. B., Lohani, V. K., Mallikarjunan, P., Loganathan, G. V., Lo, J.L., "First-year Engineering Design from Multiple Perspectives," 9th International Conference on Engineering Education, San Juan, PR, July 23-28, 2006 a.

viii Lohani, V.K., Kachroo, P., Chandrachood, S., Zephirin, T. Loganathan, G.V., and Lo, J.L., "Mechatronics Experiment in a Freshman Year Course," to be published in the Proceedings of the 2006 International Conference on Engineering Education, Puerto Rico, July 23-28, 2006b.

${ }^{\text {ix }}$ Robson, V., Muffo, J., and Lohani, V., "The Little Engineer that could: Background, Attitudinal, and Academic Predictors of Student Success," poster presented at Association for Institutional Research Annual Forum, Chicago, IL, May, 2006.

${ }^{\mathrm{x}}$ Muffo, J., Lohani, V.K., Mullin, J., Backert, R., and Griffin, O.H. "From Engineering Fundamentals to Engineering Education - What's in a Name," Invited paper, Proceedings of the International Conference on Engineering Education, Tainan, Taiwan, March 1-5, 2005.

${ }^{x i}$ The Engineer of 2020, 2004. National Academy of Engineering publication, Web site: www.nae.edu ${ }^{x i i}$ Educating the Engineer of 2020, 2005. National Academy of Engineering publication, Web Site: www.nae.edu xiii American Council on Education, 2003, Internationalizing the campus- A user's guide, Washington D.C.

${ }^{\text {xiv }}$ Mullin, J., Jinsoo, K., and Lohani, V. K., 2007. "Sustainable Energy Design Projects for Engineering Freshmen," Proceedings of the 2007 ASEE Annual Conference and Exposition, Honolulu, HI, June 24-27, 2007. (Best Paper Award winner at 2007 ASEE Annual Conference).

${ }^{x v}$ Janis P.Terpenny, Richard M. Goff, Vinod K. Lohani, Jennifer Mullin and Jenny Lo, "Preparing Globally and Socially-conscious Engineers: International and Human Centered Design Projects and Activities in the First Year

${ }^{x v i}$ Jayaraman, P., Lohani, V., Johri, A. and Griffin, H., "Internationalizing The Freshman Engineering Program", poster presented at the Engineering Education Abroad Fair, Blacksburg, VA, October, 2007.

${ }_{\text {xvii }}$ Lohani, V., Lo, J., Mullin, J., Griffin, H., "Implementation Of International Activities In A Freshman Engineering Course”, poster presented at the Engineering Education Abroad Fair, Blacksburg, VA, October, 2007.

xviii INNOVATE conference website, http://www.innovate.rice.edu 